\title{
Aquaculture of the Southern Federal District of Russia: current status, development prospects
}

\author{
Grigory Voloshin ${ }^{1}$, Evgeny Akimov ${ }^{1}$, Marina Aleksandrova ${ }^{1,}$, Elena Ponomareva ${ }^{2}$, Diana \\ Smirnova ${ }^{3}$ \\ ${ }^{1}$ Russian Federal Research Institute of Fisheries and Oceanography, 17, V. Krasnoselskaya, 107140, \\ Moscow, Russia \\ ${ }^{2}$ Federal Research Centre The Southern Scientific Centre of the Russian Academy of The Sciences \\ (SSC RAS), 41, Chehova, 344006, Rostov-on-Don, Russia \\ ${ }^{3}$ Astrakhan State University (FSEI HE “ASU”), 20a, Tatishcheva, 414000, Astrakhan, Russia
}

\begin{abstract}
Development of aquaculture represents the major socioeconomic factor which defines not only development of the fishery industry, but also the respective federal districts, including the Southern Federal District. The developed analysis of the current state of development of aquaculture in the Southern Federal District of Russia is provided. Problems of development of aquaculture in the Southern Federal District of Russia are revealed. It is necessary to optimize technology processes in aquaculture. Optimization of technology processes will allow to achieve worthy results in this type of activity for our country. The strategy of scientific and technical development of the Russian Federation defined the directions allowing to receive scientific and technical results and to create technologies - basis of the innovative development of domestic market of products and services, and steady position of our country in foreign market. These directions will allow to provide transition to highly productive and environmentally friendly agro-and to aquaculture, production of safe and qualitative food stuffs. The technologies of commercial fish farming used in the Southern Federal District of Russia will make possible in short terms to increase quantity and production of live fish and to reduce its cost value.
\end{abstract}

\section{Introduction}

FAO experts highlight the important role of fisheries and aquaculture in terms of food, nutrition and employment for millions of people. In the diet, fish products containing animal protein are of great importance. It is known that out of $100 \mathrm{~g}$ of fish proteins, the human body assimilates only $40 \mathrm{~g}$, and out of $100 \mathrm{~g}$ of beef, only $15 \mathrm{~g}$. The human body processes proteins and digests more easily from protein. The fat of fish products is saturated with acids that lower blood cholesterol. Fish is also a source of minerals and vitamins of groups A, B, D, H, PP (the liver of cod, tuna, etc. is richest in vitamins A and D).

During rather long period the tendency to growth of volume of consumption of products made from fish and other aquatic organisms is observed. It should be noted that growth of

\footnotetext{
* Corresponding author: alexmarina@bk.ru
} 
consumption of fish exceeds growth of consumption of products from meat. Thus, the world average per capita consumption of fish in the period from 1961 to 2018 increased more than 2 times, from 9 to $21.2 \mathrm{~kg}$. Such dynamics is caused by several factors which are among such as possibility of continuous operation of stocks of water biological resources secure ability of the specified resource to self-reproduction and also the properties of fish products having beneficial effect on human health in comparison with meat products.

A statistical analysis of the consumption of products from fish and other types of aquatic biological resources by the population of different countries revealed the dependence of life expectancy on the volume of consumption of fish products (Figure 1).

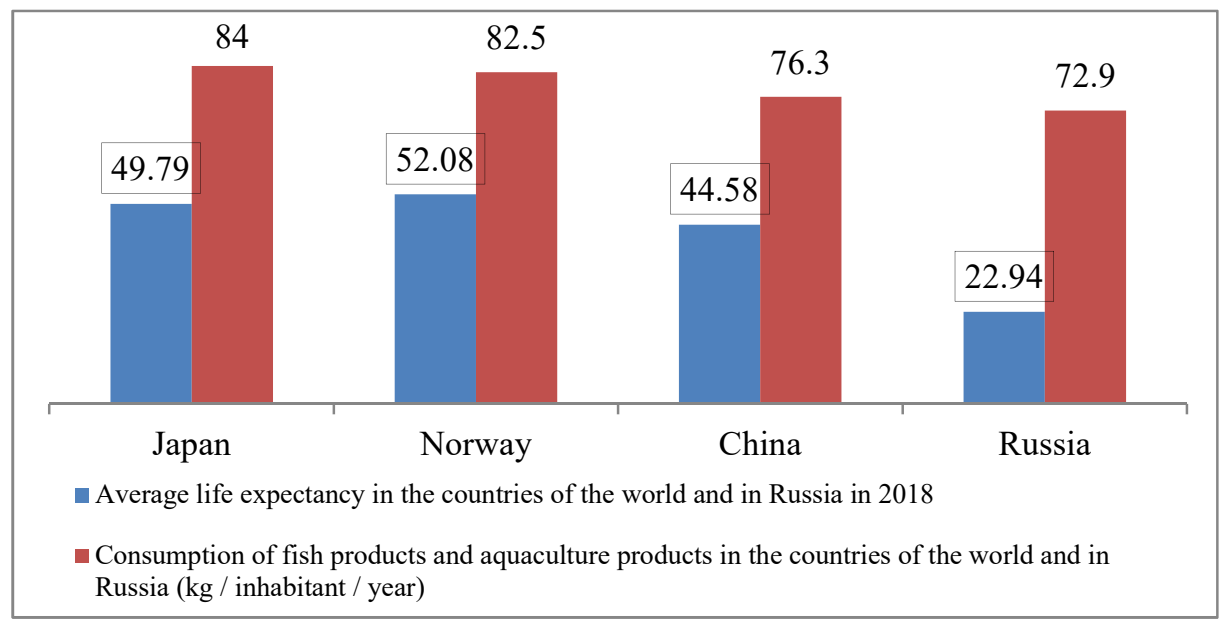

Fig. 1. Consumption of fish products, products of aquaculture and average life expectancy of the population in the countries of the world and in Russia.

An increase in the operational load on the stocks of aquatic biological resources due to the growing demand for fish products may negatively affect the ability of these stocks to self-reproduce up to their complete depletion. The current state of world stocks of aquatic biological resources is characterized by the following indicators: $7 \%$ - devastated; $17 \%$ are overdeveloped; $52 \%$ - almost completely used; $1 \%$ is on recovery [2]. So, the growth of exploitation of water biological resources in the future may lead to the formation of a complex of socio-environmental and economic problems.

Thus, the problem of satisfaction of needs of the population of the planet for fish products showing the accelerated growth forms, considering that water biological resources of the World Ocean are subject to serious depletion. One of the directions for solving this problem may be the development of industrial fish farming (aquaculture), which produces products that are an additional raw material resource. It is also necessary to take into account that the development of industrial fish farming requires a cautious approach, since in the process of activity, industrial aquaculture enterprises themselves can be sources of negative environmental impacts, and therefore cause a decrease in stocks of aquatic biological resources.

According to the UN FAO, aquaculture in the world fisheries is one of the reliable sources of providing the population with fish products and one of the fastest growing food production sectors. The share of aquaculture in the global production of products from aquatic organisms is constantly growing (Figure 3). However, despite the fact that Russia has a significant world-wide fund of inland water bodies and coastal marine areas, the volume of Russian aquaculture production is less than $1 \%$ of global production. There is a lag in this type of activity even in comparison with countries that do not have such a rich water fund. In the total supply of Russian products from aquatic biological resources, the 
share of aquaculture remains at a relatively low level $(3.7 \%$, or 239 thousand tons of fish products in 2018).

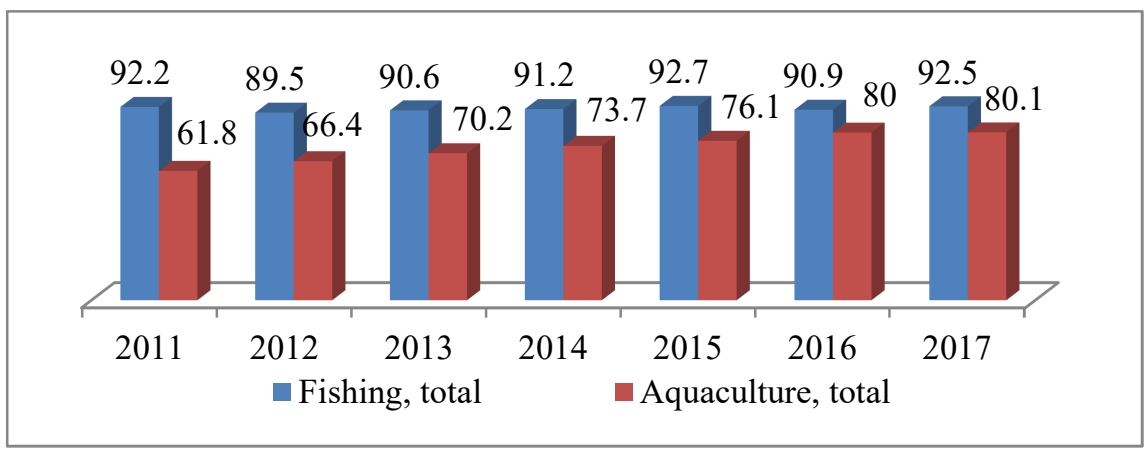

Fig. 2. Production and use of world fisheries and aquaculture products, million tons.

Thus, the level of development of commercial fish farming and the use of resource potential for aquaculture currently remains quite low.

The purpose of the study is to analyze the current state of aquaculture development in Russia (using the example of the Southern Federal District), identify the main problems and suggest ways to solve them.

\section{Results and Discussion}

Aquaculture, in particular commercial fish farming, plays an important role in ensuring the food security of the country, participates in the formation of the socio-economic effect of the industry, and also contributes to the development of the economy of the constituent entities of the Russian Federation. Considering the importance of aquaculture, an active state policy is being implemented in the Russian Federation aimed at its support and development, with commercial fish farming being a priority [3]. According to the State Program of the Russian Federation "Development of the fisheries complex", approved by Decree of the Government of the Russian Federation dated April 15, 2014 No. 314, annual target indicators of the volume of production of commercial aquaculture products, including fish planting stock, were established [6] (table 1).

Table 1. Planned and actual values of indicators (indicators) of the State Program of the Russian Federation "Development of the fishery complex".

\begin{tabular}{|c|c|c|c|c|c|c|c|c|c|c|c|}
\hline \multirow{3}{*}{ Indicator } & \multirow{3}{*}{ Units } & \multicolumn{10}{|c|}{ Indicator values } \\
\hline & & \multicolumn{2}{|c|}{2015 year } & \multicolumn{2}{|c|}{2016 year } & \multicolumn{2}{|c|}{2017 year } & \multicolumn{2}{|c|}{2018 year } & \multicolumn{2}{|c|}{2019 year } \\
\hline & & plan & fact & $\begin{array}{c}\text { pla } \\
\text { n }\end{array}$ & fact & $\begin{array}{c}\text { pla } \\
\text { n }\end{array}$ & fact & plan & fact & plan & $\begin{array}{c}\text { fact } \\
*\end{array}$ \\
\hline $\begin{array}{l}\text { The } \\
\text { volume of } \\
\text { production } \\
\text { of } \\
\text { commercia } \\
1 \\
\text { aquacultur } \\
\text { e products, } \\
\text { including } \\
\text { fish } \\
\text { planting }\end{array}$ & $\begin{array}{c}\text { thousan } \\
\mathrm{d} \text { tons }\end{array}$ & $\begin{array}{c}179 \\
6\end{array}$ & $\begin{array}{c}177 \\
9\end{array}$ & 199 & $\begin{array}{c}205 \\
3\end{array}$ & 203 & $\begin{array}{c}219 \\
7\end{array}$ & $\begin{array}{c}207, \\
3\end{array}$ & $\begin{array}{c}238 \\
6\end{array}$ & $\begin{array}{c}215 \\
6\end{array}$ & $\begin{array}{c}285 \\
9\end{array}$ \\
\hline
\end{tabular}




\begin{tabular}{|l|l|l|l|l|l|l|l|l|l|}
\hline stock & & & & & & & & \\
\hline $\begin{array}{l}\text { Performan } \\
\text { ce of } \\
\text { planned } \\
\text { targets }\end{array}$ & $\%$ & 99,05 & 103,17 & 108,23 & 115,10 & 132,61 \\
\hline
\end{tabular}

Where: *- According to the operational data of the Federal Agency for Fisheries.

The data in Table 1 show that, despite the positive dynamics in the period from 2015 to 2019 , the volume of aquaculture production in 2015 was lower than the planned indicators $(99.05 \%)$. In 2016, the volume of production of commercial aquaculture products (including planting stock) reached the level of 205.3 thousand tons, exceeding the target by $3.17 \%$. In the period from 2017 to 2019 , the growth in aquaculture production not only persisted, but also increased the pace, while the growth in relation to the planned indicator as a percentage also shows a positive trend (in $2017-108.23,2018-115.1,2019-132.61$ ). In relation to the level of 2015 (177.9 thousand tons), the volume of production of commodity fish farming in 2019 increased by $60.71 \%$ (Figure 3). The average annual growth rate for the period 2015 - 2019 amounted to $12.7 \%$ [5].

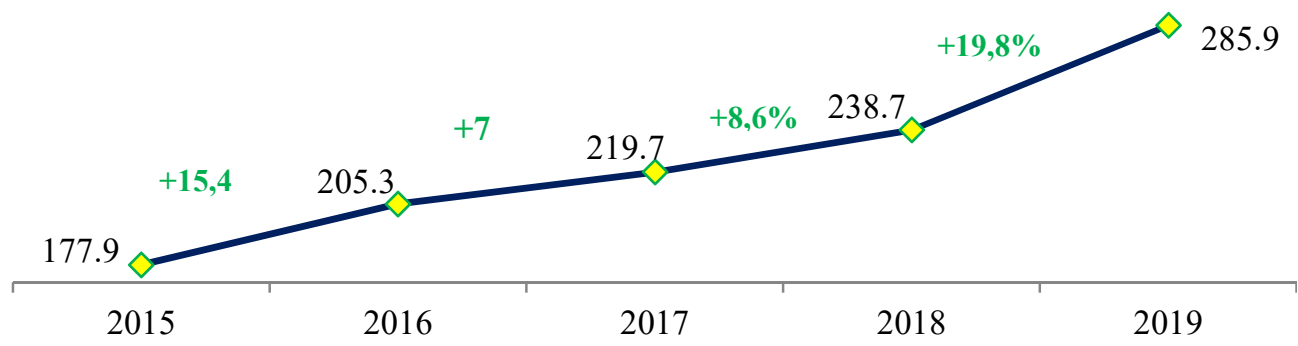

Fig. 3. Dynamics of the volume of Russian production of commercial fish farming products (including fish stocks) for 2015 - 2019, thousand tons.

The modern breeding base of commercial fish farming includes: breeding achievements, pedigree fish farms, reproducers, industrial farms, which determine the volume of production of commercial fish farming. In Russia 23 farms have the status of the breeding fish-breeding organizations, in 13 of them work on cyprinid species of fish, in 5 - on herbivorous fishes, in 6 - on trout and in two - on sturgeon is conducted.

In accordance with the territorial features of the country, industrial fish farming in Russia is located in 6 geographical zones, differing in natural and climatic conditions. The most favorable natural and climatic conditions for the development of aquaculture are in the 5 th and 6th zones of fish farming. These zones are located mainly in the Southern Federal District [13]. This favorable fact makes it possible for the Southern Federal District to occupy a leading position in the production of marketable fish in Russia. The Southern Federal District accounts for about 34\% (69.2 thousand tons) of the total volume of Russian commercial aquaculture products (Figure 4). The increase in the volume of commercial cultivation of aquaculture facilities in 2018 compared to 2015 amounted to $22.7 \%$, or 12.8 thousand tons. Along with the Southern Federal District, the North-Western and Central Federal Districts are among the leaders in the production of commercial fish products in the country. The total share of leading districts is over $72 \%$ of total aquaculture production. 


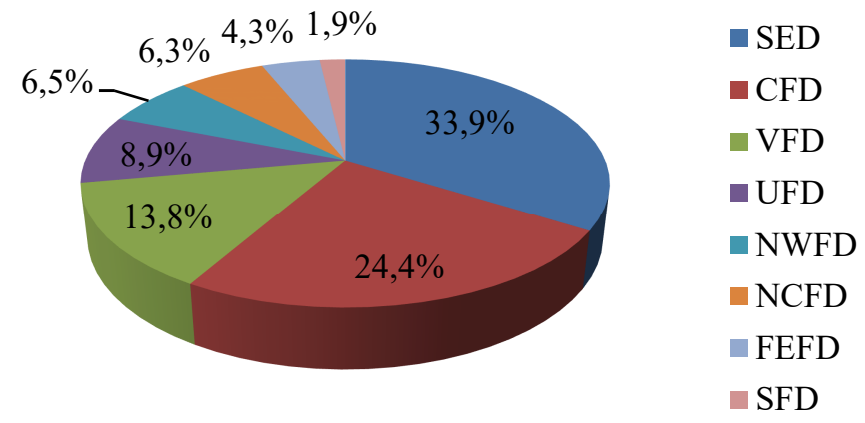

Fig. 4. Shares of the Federal Districts for the production of commercial fish for 2018.

The species structure of aquaculture production in the Southern Federal District is determined by climatic and economic factors. The warm climate, the natural fertility of the ponds, as well as the presence of large organizations ( 8 pedigree farms, including the OOO "Rybopitomnik CHaganskij", PAO "Sirius"), which can provide with fish planting stock (developing fish larvae), full-system fish farms and farms are important factors cultivation of herbivorous fish species, which allows to obtain high rates for their cultivation $(54.5 \%)$. An important area of aquaculture in the Southern Federal District is multi-commodity commercial fish farming (co-production of cyprinids). In general, in the Southern Federal District, multicultural fish farming is significantly approaching the optimal level. Bringing the share of herbivorous fish to $55-60 \%$ in all regions of the district is an important reserve for increasing the production of marketable fish (Fig. 5) [15].

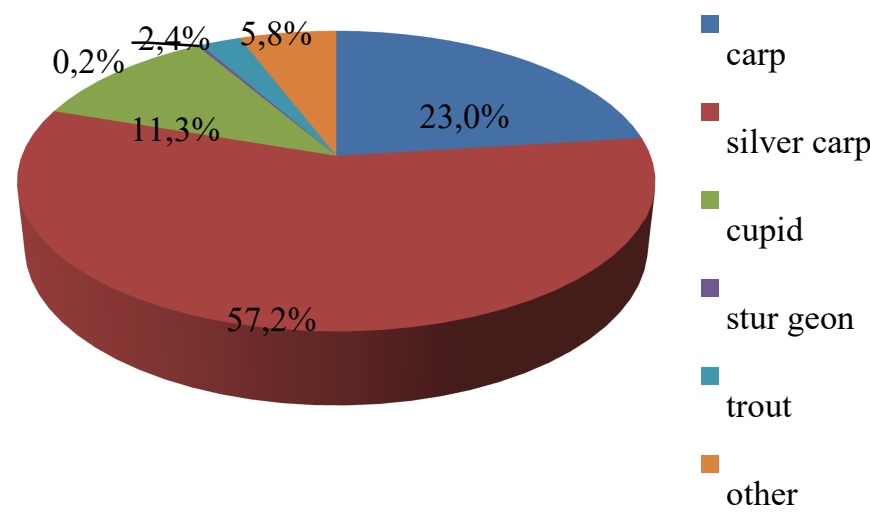

Fig. 5. The main fish species in the Southern Federal District for 2018.

On the volume of cultivation of marketable fish in the Southern Federal District invariable leaders in 2018 are Astrakhan Region (21.3 thousand tons), Rostov Region (23.5 thousand tons) and Krasnodar Krai (19.8 thousand tons). Development of aquaculture in these areas develop in the following directions: pond, industrial aquaculture on warm waters of nuclear power plants, pasture aquaculture in lakes, reservoirs and estuaries.

The volume of commodity fish in the Astrakhan Region, Rostov Region and Krasnodar Krai steadily increases. So the gain of volume of commercial cultivation of objects of aquaculture in these regions in 2018 in relation to 2014 made $22.8 \%$ or for 12 thousand tons in kind. The main subjects to commercial cultivation in 2018 in these areas were the carp, silver carp, grass carp, sturgeon and trout. 


\section{Astrakhan Region}

Astrakhan region is characterized by huge fish-breeding resources and has high potential of production of marketable fish. In the area 140 enterprises, from them 6 sturgeon fish farms on artificial reproduction and 36 enterprises of industrial aquaculture which are included into "Astrakhanrybkhoz" association function. Now cultivation of cyprinid species of fish (carp, white silver carp, grass carp) is carried out in ponds or in natural bodies of water which total area reaches 32 thousand hectares.

The mains subjects to commercial cultivation in 2018 are herbivorous fishes $(12.1$ thousand tons), carp (6.1 thousand tons). Production on large water areas, has extensive character, and the fish productivity is not more than 3.5 - 5 centers/hectare. Increase in commercial fish farming is reached generally at the expense of number of fish-breeding farms and expansion of the feeding ponds adapted for fish farming. Volume reached cultivation of sturgeon species of fish in $2018-1.2$ thousand tons.

The reasons for the extensive development of commercial fish farming in the Astrakhan Region are the high prices of specialized feed, which forces fish farms to grow fish on a natural forage basis; lack of quality highly productive breeding material; weak introduction of new polyculture objects (grass carp, so-iuy mullet, paddlefish). In addition, sturgeon breeding should become the most important direction for the further development of commercial fish farming.
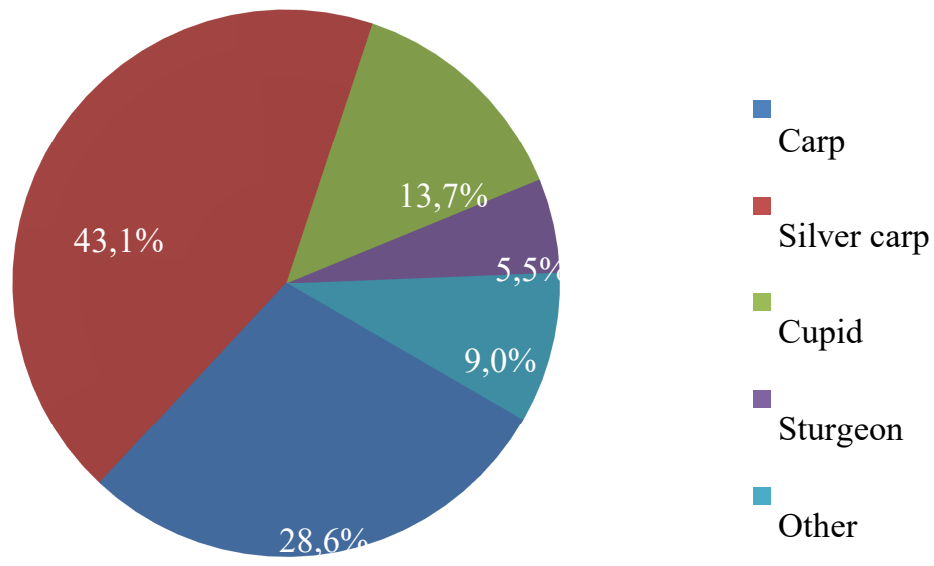

Fig. 6. The main subjects to commercial cultivation of fish in the Astrakhan Region in 2018.

\section{Rostov Region}

In the region there are 22.7 thousand hectares of feeding ponds and 2.7 thousand hectares of growth ponds for fish (Figure 7). About $80 \%$ of feeding areas and about $70 \%$ of those grown for the production of fish planting stock are used to grow salable fish. Commercial fish are grown by 24 specialized aquaculture enterprises and more than 300 small enterprises and entrepreneurs. Along with many farms in the region, large hatchery organizations producing 500-1000 and more tons of marketable fish per year are widely represented. Also, industrial aquaculture is developing in the region in cages and pools, where in 2018 the cultivation of sturgeon species amounted to 2 tons.

The leader in production of commodity aquaculture is "OOO Abramov's Fish Farm". In this organization 4500 - 5000 tons of commodity fish with use of technology of cultivation of fish in two and three-year cycle are produced. Fish productivity of feeding ponds on this 
economy makes on carp 16.3 centers/hectare, to motley and white silver carp of $1.5-3.5$ centers/hectare, grass carp of 0.7 centers /hectare, the general fish productivity of 22.0 centers/hectare.

In the Rostov Region, one of the main reasons for the insufficient development of commercial fish farming is the poor use of pedigree fish stock. The breeding product created on the basis of OOO «Slobodskaya sagva» is currently a first-generation carp hybrid. However, the introduction of carp hybrids (F-1) into industrial production remains low. It restrains the development of commercial fish farming in the region and the low cultivation of non-traditional objects (catfish, pike perch, vimba vimba, pike).

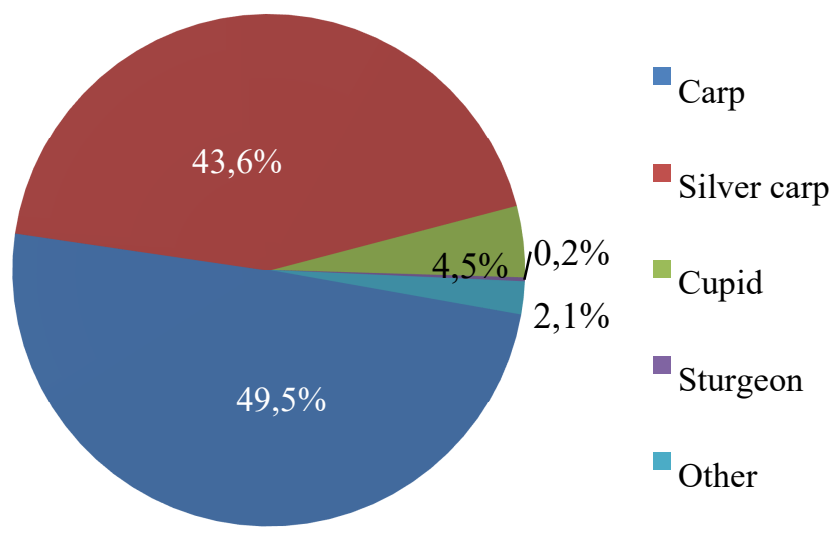

Fig. 7. The main subjects to commercial cultivation of fish in the Rostov Region in 2018.

\section{Krasnodar Krai}

The water fund of Krasnodar includes more than 20.0 thousand hectares of pond areas of specialized fish farms, about 40.0 thousand hectares of channel reservoirs. The area of nurseries for the cultivation of fish planting stock is 3.5 thousand hectares. Also, for fish farming in the Krasnodar, more than 30.0 thousand hectares of estuaries suitable for grazing fish can be used. Pasture fish farming is one of the priority development of aquaculture in southern Russia. The basis for the creation of pasture fish farms are lakes, reservoirs, estuaries, and ponds for general purposes.

The area of 140 estuaries in the Krasnodar Krai, with a fishery purpose, is 198.2 thousand square kilometers, 4 reservoirs - 53.6 thousand square kilometers [14]. More than half of the production of carp and other herbivorous fish (61\%) in the Krasnodar Krai is grown in pasture fish farming. Currently, 80 enterprises engaged in pasture fish farming are operating in the territory of the region.

In the Rostov and Astrakhan regions, the pasture cultivation of carp and herbivorous fish in 2018 amounted to 2.5 and 6.6 thousand tons, respectively. In 2018, the region's enterprises grew carp - 4.5 thousand tons, silver carp - 11.3 thousand tons, grass carp - 2.2 thousand tons. Recently, industrial fish farming for the production of trout and sturgeon species has been developing in the region. The volumes of cultivation of these species are in the range of 450 - 500 tons and 22 tons, respectively. Constraining factors in the development of commercial fish farming in the Krasnodar are: unsatisfactory condition of the breeding base; poor introduction of polyculture (carp, grass carp). In pasture fish farming, there is an intensive overgrowing of water bodies by aquatic vegetation, which leads to a sharp reduction in spawning areas and fish reproduction volumes. 


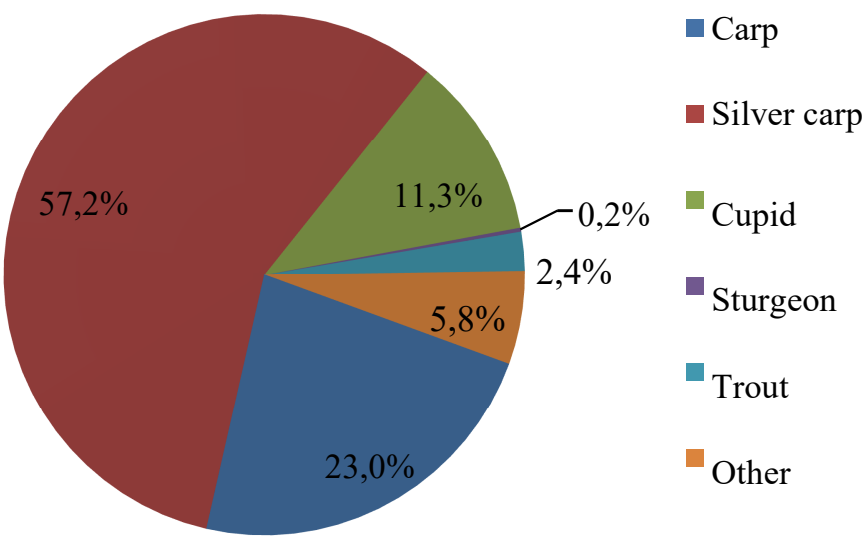

Fig. 8. The main subjects to commercial cultivation of fish in the Krasnodar Krai in 2018.

Thus, in the Southern Federal District, the following areas can be distinguished for increasing the production of commercial fish farming, which are also characteristic in other districts of the Russian Federation. One of the main directions is to increase the efficiency of hatcheries by improving the quality of breeding and increasing the cultivation of planting stock with an increased weight standard (weight of fish is over 100 grams of annuals). Due to the fact that many farms of the country are switching to fish farming with the help of large fish planting stock of highly productive fish species, it is necessary to strengthen the vertical structure of interaction and cooperation between pedigree farms and commercial fish farms. The widespread adoption of high-performance hybrids (F-1) is the most important reserve for increasing the production of marketable fish.

The transition and use of high-quality feeds, which have a higher cost than traditional feeds, requires government support for their production and consumption. This is especially important for sturgeon breeding, which should develop at an accelerated pace. The increase in the cultivation of marketable fish should be facilitated by the optimization of pond polyculture and the introduction of new facilities (grass carp, so-iuy mullet, paddlefish, etc.), as well as the cultivation of non-traditional facilities used in biological ponds as biological species that can increase the productivity of fishery reservoirs (zander (pikeperch), pike, etc.).

The development of commercial fish farms in the Southern Federal District is associated with the cultivation of especially valuable fish species (salmon, trout, sturgeon, clari, etc.), which are installed in installations with a closed water supply system, as well as in fish breeding areas using garden pools. In order to ensure production growth by the most valuable fish species and increase production efficiency.

\section{Conclusion}

Analysis of the development of aquaculture in the Southern Federal District suggests that the selection of breeding sites was made with the characteristics of regional features. Selected objects can be conditionally divided into two groups. The first group is represented by objects of fauna, evolutionarily adapted to the conditions of reservoirs of a certain area, which include carp, silver carp, catfish, grass carp and several others. Presented objects are traditional objects of pond, lake, industrial fish farming and recreational fish farming. To accelerate the development of aquaculture of the above objects, as noted earlier, it is necessary to optimize technological processes, and to develop and introduce new biotechnologies in fish farms of the Southern Federal District. We 
emphasize need of expansion of implementation of "green" technologies for these subjects to commodity cultivation, it will allow to pass to ecological management (combating water, air pollution, waste management), energy production from renewable sources (solar energy, biofuel), reducing harmful emissions in atmosphere [7]. The developing trend is represented by a complex multi-trophic aquaculture in which species that need feeding (herbivorous fish species) are grown together with organisms that feed on dissolved nutrients or organic waste, it can be algae, green plant crops [9, 11].

The second group consists of objects that are advisable to grow in an industrial environment, this group includes trout, sturgeon and others [1, 4]. New biotechnologies in sturgeon breeding have already been developed and are being gradually introduced at fish farms. The Southern Scientific Center of the Russian Academy of Sciences (SSC RAS) has created a comprehensive biotechnology for producing environmentally friendly sturgeon fish products, which eliminates climate risks. This biotechnology is presented as a set of techniques and methods for fish cultivation under completely controlled conditions using a modular installation-complex, built according to the type of intensified production based on modern scientific achievements. The modernized methods developed at present make it possible to stably produce the final product (marketable fish, caviar) within the specified time period for 12 months with the required size and mass characteristics of 1.5-2.0 kg, which are in demand on the market $[8,10]$.

Of particular interest are intensive cultivation methods for producing food products using recycled, waste water and sludge from closed water supply systems in specialized modular systems that have technical characteristics close to world analogues. Special block-modular systems and biotechnological methods have been developed for various aquatic organisms (fish, crayfish and plant crops), which imply high plant densities from 60 - $80 \mathrm{~kg} / \mathrm{m} 3$ to $100 \mathrm{~kg} / \mathrm{m} 3$ and a high yield from a useful area of 85 to $95 \%$, as well as biological water purification with highly efficient filtration, and the use of filtering facilities (plants) for additional purification. The peculiarity of this biotechnology is the actual wastefree production. As the main object of aquaculture of this technology, it is possible to use hybrids of sturgeon, catfish, tilapia and Australian cancer, as an additional biological treatment, plant crops (lettuce, dill, parsley) can be used [8, 12].

In our opinion, a global technological breakthrough in accelerating the development of aquaculture in the Southern Federal District is possible due to continued development and collaboration, but at a more intensive level in the following areas:

$\checkmark$ selection of aquaculture objects using genomic methods and bioinformatics;

$\checkmark$ closed systems of industrial aquaculture;

$\checkmark$ integrated technologies for the deep processing of aquatic organisms;

$\checkmark$ alternative sources of raw materials for feed production;

$\checkmark$ systems of integrated pasture, pond, multi-trophic and recircular aquaculture;

$\checkmark$ algo-totechnology for aquaculture; systems of intellectual, adaptive feeding of fish; feed for various aquaculture facilities.

According to the authors, the development directions proposed above are relevant not only for the Southern Federal District, but also for the development of aquaculture in Russia as a whole. The implementation of the proposed areas will contribute to the achievement of the planned indicators (618 thousand tons) of the "Development Strategy of the Fisheries Complex of the Russian Federation for the period up to 2030", this indicator was approved by the order of the Government of the Russian Federation dated November 26, 2019 No. 2798 - p. Assuming that the share of the Southern Federal District in the total production of Russian aquaculture remains unchanged (35.5\%), the projected volume of aquaculture production in 2030 in the Southern Federal District will be 203.3 thousand tons. Figure 9 presents the forecast for the volume of aquaculture production in the Southern Federal District up to 2030. 


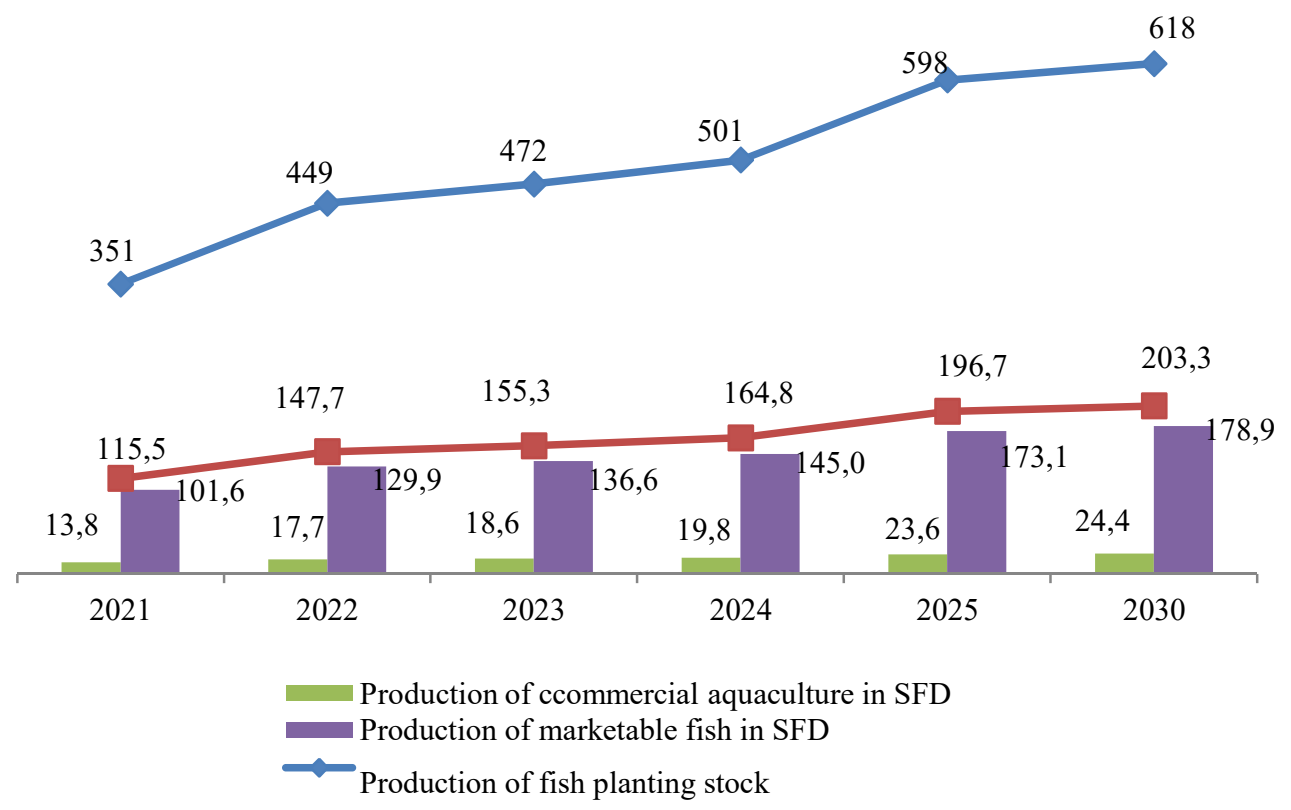

Fig. 9. Trending models of commodity aquaculture indicators.

Thus, in the Southern Federal District of Russia there are wide opportunities for the development of aquaculture, this can become an essential basis in providing the population with nutritious food and increasing the average consumption of fish products in our country.

\section{References}

1. Eurofish Magazine 4, 52-55 (2019)

2. G.G. Matishov, E.N. Ponomareva, V.A. Grigoriev, Aquaculture Europe 2017 (Dubrovnik, Croatia, 2017)

3. G.G. Matishov, E.N. Ponomareva, M.N. Sorokina, Aquaculture Europe (Berlin, Germany, 2019)

4. A.A. Krasilnikova, E.N. Ponomareva, A.M. Tikhomirov, A.V. Firsova, International Conference and Exposition "Aquaculture America 2017» (San Antonio, Texas USA, 2017)

5. G.G. Matishov, E.N. Ponomareva, M.N. Sorokina, V.A. Grigoriev, Aquaculture Europe (Dubrovnik, Croatia, 2017)

6. K.D. Matishov, U.S. Aleksandrova, Aquaculture Europe - 2017 (Dubrovnik, Crotia, 2017)

7. G.G. Matishov, E.N. Ponomareva, Aquaculture America (New Orleans, Louisiana, USA, 2019)

8. G.G. Matishov, P.A. Balykin, E.N. Ponomareva, Herald of the Russian Academy of Sciences 82(1), 55-62 (2018)

9. C. Platon, Eurofish Magazine 5, 20-22 (2019)

10. E.N. Ponomareva, G.G. Matishov, V.A. Grigori'ev, Aquaculture America 2015 (New Orleans, Louisiana, USA, 2015) 
11. E.N. Ponomareva, A.V. Kovaleva, V.A. Grigorev, A.V. Firsova, Aquaculture 2019 (New Orleans Marriott, Louisiana, 2019)

12. G.G. Matishov, E.N. Ponomareva, Thesis of International conference World Aquaculture (Jeju, Korea, 2015)

13. E.N. Ponomareva, V.A. Grigor'ev, Thesis of International conference World Aquaculture (Jeju, Korea, 2015)

14. U.S. Aleksandrova, T.S. Gridina, K.D. Matishov, A.A. Kuzov, Aquaculture (New Orleans, Louisiana, 2019)

15. U.S. Aleksandrova, T.S. Gridina, K.D. Matishov, A.A. Kuzov, Aquaculture Europe2019 (Berlin, Germany, 2019) 